TITLE:

\title{
BACTERICIDAL AND MEMBRANE DISRUPTION ACTIVITIES OF THE EOSINOPHIL CATIONIC PROTEIN ARE LARGELY RETAINED IN AN N-TERMINAL FRAGMENT
}

\section{AUTHORS :}

Torrent, Marc ${ }^{1}$; De la Torre, Beatriz G. ${ }^{2}$; Nogués, M.Victòria ${ }^{1}$; Andreu, David ${ }^{2}$; and Boix, Ester $^{1 \ddagger}$

${ }^{1}$ Dpt. Bioquímica i Biologia Molecular, Fac. Biociències, Universitat Autònoma de Barcelona, Cerdanyola del Vallès, Spain

${ }^{2}$ Dpt. Ciències Experimentals i de la Salut, Universitat Pompeu Fabra- Parc de Recerca Biomèdica de Barcelona, Barcelona, Spain

${ }^{*}$ To whom correspondence should be addressed

RUNNING TITLE: Antimicrobial activity of ECP N-terminus

\section{CORRESPONDING AUTHOR:}

Ester Boix

Departament de Bioquímica i Biologia Molecular

Facultat de Biociències

Universitat Autònoma de Barcelona

08193 Cerdanyola del Vallés. Spain

E-mail: Ester.Boix@uab.es Phone: 34-93-5814147 Fax: 34-93-5811264

http://bioquimica.uab.es/paginas cat/recerca_grups.php

\section{KEYWORDS:}

Antimicrobial peptides, host defense, electron microscopy, lipopolysaccharides, liposomes.

\section{ABBREVIATIONS NOTE}

BC (BODIPY TR Cadaverine), (5-(((4-(4,4-difluoro-5-(2-thienyl)-4-bora-3a,4a-diaza-sindacene-3-yl)phenoxy)acetyl)amino)pentylamine, hydrochloride; $\operatorname{DiSC}_{3}(5), 3,3$ -

dipropylthiacarbocyanine; AMPs, antimicrobial peptides; ECP, Eosinophil Cationic Protein; LPS, lipopolysaccharides; LTA, lipoteichoic acids; PMB, Polymyxin B; 1,2-dioleoyl-snglycero-3-phosphocholine, DOPC; 1,2 dioleoyl-sn-glycero-3-[phospho-rac-(1-glycerol)], DOPG; colony formation units (CFU), large unilamellar vesicles (LUV), circular dichroism (CD); $\mathrm{IC}_{50}$, half inhibitory concentration; MIC, minimal inhibitory concentration; DLS, dynamic light scattering; TEM, transmission electron microscopy; SEM, scanning electron microscopy. 


\section{SUMMARY}

Eosinophil cationic protein (ECP) is an eosinophil secretion protein with antipathogen activities involved in the host immune defense system. The bactericidal capacity of ECP relies on its action on both the plasma membrane and the bacterial wall. In a search for the structural determinants of ECP antimicrobial activity, we have identified an Nterminal domain (residues 1-45) that retains most of ECP's membrane-destabilizing and antimicrobial activities. Two sections of this domain, ECP(1-19) and ECP(24-45), have also been evaluated. All three peptides bind and partially insert into lipid bilayers, inducing aggregation of lipid vesicles and leakage of their aqueous content. In such an environment, the peptides undergo conformational change, significantly increasing their $\alpha$-helix content. The bactericidal activity of the three peptides against E. coli and $S$. aureus has been assessed at both the cytoplasmic membrane and the bacterial envelope levels. ECP(1-45) and ECP(24-45) partially retain the native protein ability to bind lipopolysaccharides and electron microscopy reveals cell damage by both peptides. Interestingly, the E. coli cells agglutination activity of ECP is only retained by the longest segment ECP(1-45). Comparative results suggest a task distribution, whereby residues 1-19 would contribute to membrane association and destabilization, while the 24-45 region would be essential for bactericidal action. Results also indicate that ECP cytotoxicity is not uniquely dependant on its membrane disruption capacity, and that specific interactions at the bacteria wall are also involved. 


\section{INTRODUCTION}

Host defense proteins and peptides of the innate immune system are potential candidates for chemotherapeutic development. Among those, antimicrobial peptides (AMPs) are characterized by a variety of primary and secondary structures [1] and by a broad spectra of activity. Their fast, non-specific mechanism of action [2], mostly at the plasma membrane and cell surface level, tends to make the development of resistant strains rather unlikely [3]. On the basis of these features, several native AMPs or their synthetic analogues have been proposed as alternatives to conventional antibiotics; and some of them are currently in clinical trials, mostly for topical applications [4].

Some AMPs are derived from host defense proteins by limited proteolysis that releases in vivo active fragments, often corresponding to the $\mathrm{N}$ or $\mathrm{C}$ terminus [5]. Proteolytic processing is very frequent in immunological cascade events, where local cleavage can release the active peptides in the area of infection or inflammation. There are also multiple examples of synthetic peptides corresponding to a protein $\mathrm{N}$ - or C-terminus that display antimicrobial activity [6]. Thus lactoferricin, a naturally occurring bactericidal peptide derived from the N-terminus of lactoferrin, is very effective against some antibiotic resistant strains [7]. Likewise, bactericidal permeability-increasing protein (BPI) is expressed in neutrophils and displays cytotoxicity against Gramnegative bacteria. A recombinant fragment corresponding to the BPI $\mathrm{N}$ - terminus is currently under phase III clinical trials [8]. Other examples of AMPs resulting from proteolysis include cathelicidins from neutrophils [9], and cryptdins, $\alpha$-defensins secreted by intestinal Paneth cells, whose bactericidal activity requires activation of a precursor by a metalloprotease [10].

We are currently working on eosinophil cationic protein (ECP) as a model of the potential involvement of mammalian RNases in the host defense system. ECP is a secretory ribonuclease (RNase 3 ) found in the eosinophilic leukocyte and potentially involved in innate immunity. ECP can also be expressed at lower level by activated neutrophils. Although the role of eosinophils during infection is controversial, eosinophils are activated and selectively release their content at the inflammation areas [11]. Some authors have reported antimicrobial activities for eosinophils, and proposed a complementary action together with neutrophils during bacterial infections. Besides, the protein local secretion, which can harm the own host tissues, may also participate in immunoregulation and tissue remodeling processes $[12,13]$. Although a wealth of structural and functional data have been reported, the physiological role of ECP remains elusive [14]. Its cytotoxic activity is effective against a wide range of pathogens, suggesting a relatively non-specific mechanism of action. Although there is no evidence of direct in vivo involvement of ECP in the host response to bacterial infection, ECP kills both Gram-negative and Gram-positive strains at a low micromolar range and its activity depends on its action both at the bacterial cell wall and cytoplasmic membrane levels [15-18]. ECP belongs to the vertebrate RNase A superfamily, several members of which are endowed with antimicrobial properties (Fig. 1S) [19-21], a family that may have started off playing a physiological role in the host immune system [22-24]. Interestingly, ECP antibacterial activity is not shared by eosinophil derived neurotoxin (EDN), a closely related eosinophil ribonuclease [25]. Antimicrobial RNases, as innate immune proteins with anti-infective and immunomodulatory properties, present substantial therapeutic potential in the drug development industry, both in the search of alternative antibiotics and for the treatment of inflammatory disorders.

In order to identify the structural determinants of ECP cytotoxic mechanism of action, we have searched the ECP sequence for potential active domains using a theoretical 
approach to spot key antimicrobial regions (Torrent et al., unpublished results), and have identified a potentially active region at the N-terminus. To validate our hypothesis, we have synthesized three peptides representative of this region (Fig. 1) and assessed their properties both on a synthetic membrane model and on bacterial cell cultures.

\section{RESULTS}

\section{Antimicrobial activity}

Sequence analysis of ECP suggests that the N-terminus might contain an antimicrobial domain. Applying a predictive strategy based on a previous peptide library highthroughput screening results [26], a bactericidal propensity value was assigned to each amino acid (Torrent et al., submitted). Scanning on ECP spotted a main potential active region at the $\mathrm{N}$-terminus (residues 30 to 45 ). To test this hypothesis, the full $\mathrm{N}$-terminal domain, ECP(1-45), as well as two smaller representative peptides, ECP(1-19) and ECP(24-45), have been chosen for this study (Fig. 1). ECP(1-45) includes the first ECP $\alpha$-helix elements $(\alpha 1, \alpha 2$ and $\alpha 3)$ and the first $\beta 1$ region. The $\operatorname{ECP}(24-45)$ peptide spans the main predicted sequence and includes the Trp35-Arg36 residues previously identified to be determinant for cytotoxicity and membrane lysis activity [16, 27, 28]. The ECP(1-19) peptide, which corresponds to the first $\alpha 1$ domain, represents the ECP homolog of the S-peptide in RNase A [29].

The bactericidal properties of the three peptides against two representative Gramnegative and -positive strains (E. coli and S. aureus, respectively) have been compared with those of the full ECP sequence. Analysis of the half inhibitory concentration $\left(\mathrm{IC}_{50}\right)$ and the minimal inhibitory concentration (MIC) values (Table I) shows the 1-45 segment to be practically equivalent to the entire native sequence in terms of antimicrobial activity against both strains. Within the 1-45 segment, activity is shown to be mostly confined to residues $24-45$, while the 1-19 peptide requires about 10-20 times higher concentrations to display significant bactericidal activity. As shown in Table 1, ECP and the three tested peptides displayed similar active ranges against both E. coli and $S$. aureus.

The bactericidal effects of the peptides on either strain have been further analyzed to better characterize their distinct properties. ECP can depolarize the cytoplasmic membrane of both E. coli and S. aureus cells [17]. The evaluation of the protein capacity to depolarize the bacteria cytoplasmic cell is an indirect method to assess its ability to interact at the bacteria surface and alter the inner membrane. Previous results on ECP depolarization capacity indicated that its activity is higher in the Gram-negative tested strain, probably as a consequence of the easier access of the protein to the cytoplasmic membrane. In fact, ECP can alter by itself the Gram-negative strain outer membrane structure [17]. We have now compared the protein depolarization capacity with the corresponding N-terminal peptides (Fig. 2). ECP(1-45) is the most active segment while ECP(24-45) retains an intermediate activity and $\operatorname{ECP}(1-19)$ shows the worst performance, as previously observed for the corresponding bactericidal values (Table I). However, significant differences between the two strains are also found. While in E. coli ECP(1-45) and ECP(24-45) have both intermediate activity and ECP(1$19)$ is quite inactive, in $S$. aureus ECP(1-45) is nearly equipotent with ECP, and ECP(1$19)$ is totally inactive.

For a better understanding of the cytotoxic activities of the peptides on bacteria we have analyzed their effects by electron microscopy. Potential damage on both the bacteria wall surface and the cytoplasmic membrane can be visualized by transmission electron 
microscopy (TEM). In E. coli, ECP promotes outer membrane detachment, alteration of the overall cell shape and partial loss of cell content [17]. Comparison of the peptides with ECP confirms that both $\mathrm{ECP}(1-45)$ and $\mathrm{ECP}(24-45)$ are very active against E. coli (Fig. 3). TEM micrographs include many hypodense damaged cells with vacuolization, local outer membrane detachment and loss of characteristic baton-shaped morphology. In contrast, practically no damaged cells can be seen upon treatment with ECP(1-19). For S. aureus (Fig. 2S), TEM micrographs also show some hypodense cells for ECP(1$45)$ and $\mathrm{ECP}(1-45)$, although the overall damage is comparatively much more reduced for this strain. ECP(1-45) relative damage is similar to ECP, while ECP(24-45) is slightly less active. As above, no significant effect is visible for $\operatorname{ECP}(1-19)$.

Complementary analysis by SEM further illustrated the effect of the peptides on the bacterial surface. For ECP, previous data indicated a high ability to aggregate E.coli cells and to damage their wall envelope [17]. This cell agglutination ability is retained by $\operatorname{ECP}(1-45)$ (Fig. 3), while no aggregates are observed upon incubation with the shorter peptides ECP(24-45) and ECP(1-19). On the other hand, significant surface wall damage is patent for cells treated with both ECP(1-45) and ECP(24-45), while little effect is registered upon incubation with ECP(1-19). SEM micrographs of ECP-treated $S$. aureus cells did not reveal any aggregate, as already reported [17]. Surface wall damage for $S$. aureus cells is only mild compared to the treated E. coli cells and some local blebs appear. Cells incubated with ECP(1-45) show nearly the same pattern, while with $\operatorname{ECP}(24-45)$ wall damage is quite mild, and undetectable with ECP(1-19) (Fig. 2S). Outer membrane detachment, visualized by electron microscopy, is considered to be related to ECP uncommonly high ability to bind lipopolysaccharides (LPS), the main component of Gram-negative bacterial surfaces, and its antigenic portion, the lipid A [17]. We have now compared the LPS binding capacity of ECP and its N-terminal fragments. A decreasing order of LPS binding abilities, from $\operatorname{ECP}(1-45)$ to ECP(1-19) is registered (see Table II and Fig. 3S). The displacement ability of ECP(1-45) is considerably lower than that of ECP, but still high if compared with the positive control polymyxin B (Fig. 3S). On the contrary, ECP(1-19) does not have any significant affinity to LPS. The LPS binding process can also be followed by the analysis of the intrinsic fluorescence spectra (see Table II). The recorded blue shifts suggest that Trp residues are involved in the interaction and that Trp35 might be the one which mostly alters its environment upon binding. On the other hand, while the native protein does not modify its overall structure upon LPS binding, as assessed by CD spectra, we observe significant changes for the peptides, with an increase in their secondary structure content (Fig. 6). The near UV spectra indicate that changes at the aromatic residues local environments take place in the presence of LPS. A careful inspection reveals that while ECP(1-19) does not modify significantly its overall profile, both ECP(1-45) and ECP(24-45) register an altered profile. In particular, ECP(1-45) shifts drastically the bands in the characteristic ranges for Tyr and Trp, suggesting the involvement of Tyr33 and Trp35 exposed residues in the LPS binding. Interestingly, both ECP(1-45) and ECP(24-45) peptide far UV spectra in the presence of LPS indicate a much more structured conformation upon binding (Fig. 6).

Additionally, in order to identify potential interactions between the protein and the Nterminal peptides at the Gram-positive bacteria surface, we have also analyzed the changes at the intrinsic fluorescence spectra in the presence of lipoteichoic acids (LTA). Electrostatic interactions between the polypeptide cationic residues and the negative charged groups of LTA are expected. Results confirmed the binding of LTA and the contribution of Trp residues (Table II). Pronounced shifts are mainly recorded for ECP(1-45) and ECP (24-45) peptides, with comparable values, while the blue shift 
corresponding to the $\mathrm{ECP}(1-19)$ is only minor, suggesting the involvement of Trp35 in the interaction.

\section{Interaction with lipid bilayers}

The correlation between ECP cytotoxic activity and its membrane destabilizing capacity has been previously reported [27, 28]. Detailed analysis of ECP action using large and giant unilamellar vesicles as membrane models revealed aggregation and leakage activities at a nanomolar range $[16,18]$. In the present work, we have characterized the interaction of ECP N-terminal peptides with LUV vesicles made up of DOPC/DOPG phospholipids.

The intrinsic fluorescence signals of the peptides were first analyzed. ECP includes two Trp residues, Trp10 and Trp35, both present in the studied ECP peptides, that have been classified into different spectral classes [30]. Comparison of ECP with single Trp mutants indicates that most of the blue shift in the fluorescence spectrum is due to the association of solvent-exposed Trp35 with the lipid bilayer [16]. The intrinsic fluorescence spectra of the peptides (Fig. 4S) indicate that, as expected, both Trp residues are now much more solvent-exposed than in their respective locations within the protein. Of the two, Trp10 is the residue experiencing a more pronounced change, from a buried location in ECP [16] to a more exposed position in ECP(1-19).

When the peptide spectra are recorded in the presence of the DOPC/DOPG LUVs, a significant blue shift is observed in all cases, confirming the interaction with the lipid bilayer. Shifts for ECP(24-45) and ECP(1-45) are more pronounced than for ECP(1-19), suggesting that Trp35 does undergo a more pronounced change on its microenvironment when the peptides associate to the lipid bilayers. In fact, the similarity between spectra of $\operatorname{ECP}(24-45)$ and $\operatorname{ECP}(1-45)$ suggests that Trp10 contribution to the final signal is minor.

The interaction with lipid bilayers has been further investigated by fluorescence quenching experiments using brominated phospholipids. For that purpose, LUVs made up of DOPC:DOPG with PC dibromo derivates at several positions remote from the head group $(6,7 ; 9,10$ and 11,12 , respectively) have been prepared. This methodology allows an estimation of the degree of peptide insertion into the lipid bilayers. The quenching efficiency of the differently brominated lipids has been recorded by comparing the respective fluorescence quenching slopes. For all peptides, the presence of either Trp10 or Trp35 has allowed to monitor changes upon membrane interaction. The Stern- Volmer quenching slopes show a steep decrease from the 6,7- to the 11,12dibrominated LUVs, indicating a diminishing interaction between the Trp residues and the bromine-labeled phospholipid (Fig. 5S). From these data, an average insertion of ca. $10 \AA$ (from the bilayer center) can be estimated for the Trp residues of both ECP(24-45)

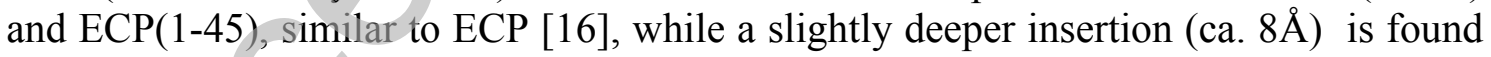
for the ECP(1-19) peptide (Fig. 4).

Another way to evaluate lipid bilayer destabilization is determining the ability to aggregate lipid vesicles and to trigger the leakage and release of aqueous content. Thus, ECP promotes the release of encapsuled ANTS/DPX at 1/300 protein/lipid ratio and above [16]. In tune with above trends, the leakage ability of ECP(1-45) is similar to $\mathrm{ECP}$, that of $\operatorname{ECP}(24-45)$ is slightly lower, while $\operatorname{ECP}(1-19)$ requires much higher peptide/lipid ratios to induce significant leakage (Fig. 5.A).

Liposome aggregation can also be monitored by the increase of scattering intensity at $470 \mathrm{~nm}$. By this method, ECP has detectable LUV aggregation above 1/1500 protein/lipid molar ratio [16], which is mostly retained by $\operatorname{ECP}(1-45)$ but somehow 
surprisingly lost in the $\operatorname{ECP}(24-45)$, while partial aggregating behavior is noted for ECP(1-19) (Fig. 5.B).

Finally, we have used circular dichroism (CD) to investigate the conformational changes brought about by peptide- membrane interaction (Fig. 6). The CD spectrum of ECP in aqueous solution has been reported [31], with the inferred secondary structure values showing some deviation from those derived from X-ray crystallography [32]. Those differences were mainly attributed to the contribution of aromatic amino acid side chains to the spectral profile. Comparison of the near UV spectra of ECP and the peptides (Fig. 6) reveals significant changes at the aromatic residues local environment for $\operatorname{ECP}(1-45)$ and $\operatorname{ECP}(24-45)$.

We have also analyzed the far UV spectra for ECP and the derived peptides in the absence and presence of SDS (Fig. 6). ECP data indicates that no overall conformation changes have taken place. In contrast, for the three peptides some significant differences were observed. SDS induced mainly the transition to more structured conformations for the three peptides, where a reduction of the $\beta$-sheet content and a significant increase in the $\alpha$-helical content is registered. Thus we can conclude that when exposed to a lipid environment the peptides undergo conformational reorganization, increasing considerably their structured content. Comparison of the $\alpha$-helix content for each peptide indicates an increase of 25,35 and $70 \%$ for $\operatorname{ECP}(1-19), \operatorname{ECP}(24-45)$ and ECP(1-45) respectively. This is in tune with the respective abilities to disrupt lipid bilayers (Fig. 5.A). On the other hand, prediction of potential transmembrane segments using the MPEx software identifies a segment from residues 9 to 27 with a high tendency to form $\alpha$-helix in a lipid environment. This might explain why the peptide with the highest activity on lipid bilayers is ECP(1-45), which includes this segment in its entirety.

\section{DISCUSSION}

ECP is an eosinophil-secreted protein involved in inflammation processes with diverse antipathogen properties $[14,33]$. In previous works we have characterized its bactericidal activity, and identified some structural determinants for its cytotoxic capacity $[16-18,28]$. ECP diverged from the other eosinophil RNase, EDN, under an unusual evolutive pressure and acquired a higher cationicity and cytotoxicity [34]. We have now identified an $\mathrm{N}$-terminal region that retains both the bactericidal and membrane-disrupting activities of ECP. The selected 1-45 segment fulfills the common structural- chemical criteria for AMPs $[1,35,36]$. It includes a high number of Arg residues which confer the three synthetic peptides a net positive charge $[+2,+5$ and +8 for ECP(1-19), ECP(24-45) and ECP(1-45), respectively] as well as a high pI (predicted as 12, 11.5 and 11.9). On the other hand, the studied $\mathrm{N}$ - terminus includes two Cys residues, which were substituted in the synthetic peptides by Ser to avoid potential formation of intra or inter disulfide bridges. Although the peptides cannot reproduce the full scenario in the context of the disulfide- bonded protein structure, the use of synthetic peptides, with Cys substitutions or deletions, is an useful approach, as reported for other antimicrobial proteins [37]. In fact, some antimicrobial proteins do retain activity at their denatured state [6]. We can also find the report of an antimicrobial RNase A homolog, the salmon RNase, which preserves activity when fully denatured [20]. Moreover, the characterization of protein derived peptides was also successfully applied to the avian leukocyte RNase A homologues (Fig. 1S), where one of the peptides outside the protein scaffold retained the bactericidal activity [38]. A cationic cluster at the N-terminus was also identified for the skin derived RNase 7, another 
human RNase A homolog (Fig. 1S) that contributes to the innate immunity at the skin chemical barrier $[39,40]$.

Comparison of the bactericidal and membrane-destabilizing activities of ECP and the three synthetic peptides indicates that the ECP N-terminus retains part of the sequence determinants involved at the different levels of ECP's cytotoxic capacity. The longest 145 peptide displays nearly all the bactericidal activity of the whole protein against $E$. coli and S. aureus strains, and partially retains the LPS binding and depolarization abilities. Additionally, ECP(1-45) has almost the same membrane interaction capacity than ECP, with nearly equivalent leakage and liposome aggregation activities. For its part, the inner ECP(24-45) peptide can partially but not fully reproduce the bactericidal and membrane destabilization capacities of the intact protein and the N-terminal ECP(119) short peptide has almost completely lost its toxicity for bacterial cells.

Altogether, the results obtained reveal once again that membrane disruption cannot by itself explain the toxicity of ECP towards bacterial cells. Besides, the observed differences on the activity against Gram-negative and Gram-positive strains also suggest the involvement of strain- specific determinants in the killing events. Electron microscopy illustrates diverse abilities of the peptides at the bacterial wall surface. Similar bactericidal activities do not readily translate to bacteria wall damage, suggesting that cell viability is lost before any cell surface destruction is visualized. Although ECP and its derived peptides are bactericidal on both E. coli and S. aureus, bacterial wall damage is much more pronounced on the Gram-negative strain. ECP shows a specific capacity to destroy the E. coli outer membrane and to agglutinate the cells [17], which is only retained by the full 1-45 fragment.

The propensity of ECP and its derived peptides to bind lipid bilayers may also be facilitated by their hydrophobicity and aggregation tendency. We used the Aggrescan software [41] to screen the ECP sequence for the presence of hydrophobic patches that can favour aggregation. One such sequence is found at the ECP N-terminus (residues 8 to 16), and is not present in the other eosinophil RNase (EDN). An N-terminal aggregation domain is also identified in the skin-derived RNase 7, though not in other screened human RNases (results not shown). An exposed hydrophobic patch may promote both protein- protein and also protein-lipid bilayer interactions. The fact that ECP(1-19) partially retains a lipid aggregation ability, while the internal segment ECP(24-45) does not, also supports the presence of a potential "aggregation-promoting" domain at the ECP N-terminus end.

For its part, the other short peptide $\operatorname{ECP}(24-45)$ seems to include a key region for bactericidal action, as well as for specific binding to the bacteria wall. Both ECP(1-45) and ECP(24-45) retain part of ECP's affinity for LPS, where Tyr33 and Trp35 residues might participate in the interaction. Recent results on ECP heparin binding affinity indicate that charged and aromatic residues in the 34-38 region are involved in this selective ability [42], providing a key domain for the protein anchoring to the cell surface. Recent work by Döring and coworkers [43] on the Tyr nitration process activated during eosinophil maturation identified in ECP a unique Tyr nitration at residue 33, and suggested that Tyr nitration may modulate ECP aggregation and/or its interaction with other eosinophil proteins.

In view of all above, we submit that the 1-45 sequence of ECP embraces a main protein functional domain. We have proven that the ECP(1-45) peptide reproduces most of ECP's antimicrobial properties. The inner ECP(24-45) sequence retains the key bactericidal region, but loses some of ECP's membrane destabilizing capacities. One can plausibly propose that the first 19 residues are also necessary, either for preserving native-like conformation, or for promoting aggregation or both. While devoid of 
significant bactericidal action, this 1-19 region retains membrane- destabilizing properties, in tune with data suggesting that it includes an aggregation patch.

In any event, ECP-derived peptides can provide a model, as a novel source of AMPs as alternative antibiotics against resistant strains. The ECP E. coli cells agglutinating activity is indeed a selected property in the search of alternative antibiotics, as a mechanism to induce bacteria clearance by the host phagocytic cells [44]. Given the pharmaceutical interest on the development of new LPS binders for treatment of immune disorders, the partial LPS-binding ability at the 24-45 stretch also offers a starting template for the design of new peptide-derived immunomodulator drugs.

\section{MATERIALS AND METHODS}

\section{Materials}

1,2-dioleoyl-sn-glycero-3-phosphocholine (DOPC) and 1,2 dioleoyl-sn-glycero-3[phospho-rac-(1-glycerol)] (DOPG); 1-palmitoyl-2-stearoyl-(6,7, 9,10, and 11,12)dibromo-sn glycero- 3-phosphocholine (6,7-diBrPC, 9,10-diBrPC, and 11,12-diBrPC) were from Avanti Polar Lipids (Birmingham, AL). 8-aminonaphthalene- 1,3,6trisulfonic acid disodium salt (ANTS) and p-xylene - bis - pyridinium bromide (DPX) were from Molecular Probes, Invitrogen (Carlsbad, CA). Bovine pancreatic ribonuclease A, type XII-A; Polymyxin B sulfate, lipoteichoic acids from S. aureus, and LPS from E. coli serotype 0111:B4 were purchased from Sigma-Aldrich (St. Louis, MO). BODIPY TR cadaverine, BC (5-(((4-(4,4-difluoro-5- (2-thienyl)-4-bora-3a,4adiaza-s-indacene 3yl) phenoxy)acetyl)amino) pentylamine, hydrochloride;) and 3,3 dipropylthiacarbocyanine $\left(\operatorname{diSC}_{3}(5)\right)$ were purchased from Molecular Probes (Eugene, OR). PD-10 desalting columns with Sephadex G-25 were from Amersham Pharmacia Biotech, Uppsala, Sweden. Escherichia coli BL21DE3, Novagen (Madison, WI) and Staphylococcus aureus 502 A, ATCC (Rockville, MD) strains were used.

\section{Peptides}

Peptide ECP(1-19) was obtained from NeoMPS (Strasbourg, France). ECP(24-45) and ECP(1-45), with Cys residues at positions 23 and 37 replaced by Ser, were prepared by Fmoc solid phase peptide synthesis methods [45]. All peptides were purified by HPLC to ca. $95 \%$ homogeneity and satisfactorily characterized by MALDI-TOF mass spectrometry. Further experimental details can be found in the Supplementary material file (Figs. S6-S8).

\section{Expression and Purification of ECP}

Wild-type ECP was obtained from a human ECP synthetic gene [46]. Protein expression in the E. coli BL21(DE3) strain, folding of the protein from inclusion bodies and the purification steps were carried out as previously described [46].

\section{$I C_{50}$ determination}

Antimicrobial activity was expressed as the half inhibitory concentration $\left(\mathrm{IC}_{50}\right) . \mathrm{IC}_{50}$ of each peptide was determined from 2 independent experiments performed in triplicate for each peptide concentration. Peptides were dissolved in $\mathrm{Na}_{2} \mathrm{HPO}_{4}$ phosphate buffer, $10 \mathrm{mM}, \mathrm{pH} 7.5$ and serially diluted from $0.2 \mu \mathrm{M}$ to $10 \mu \mathrm{M}$. Bacteria were incubated at $37{ }^{\circ} \mathrm{C}$ overnight in LB and diluted to give approximately $5 \times 10^{5} \mathrm{CFU} / \mathrm{ml}$. In each assay peptide solutions were added to each bacteria dilution, incubated for 4 hours and samples were plated on Petri dishes and incubated at $37^{\circ} \mathrm{C}$ overnight. The colony 
forming units (CFU) in each Petri dish was counted, the average and the standard error calculated and represented in a semi-logarithmic plot.

\section{MIC determination}

Antimicrobial activity was expressed as the minimal inhibitory concentration (MIC), which is defined as the lowest concentration of peptides that completely inhibits microbial growth. MIC of each peptide was determined from 2 independent experiments performed in triplicate for each peptide concentration. Peptides were dissolved in $\mathrm{Na}_{2} \mathrm{HPO}_{4}$ phosphate buffer, $10 \mathrm{mM}$, pH 7.5 and serially diluted from 0.2 $\mu \mathrm{M}$ to $100 \mu \mathrm{M}$. Bacteria were incubated at $37^{\circ} \mathrm{C}$ overnight in $\mathrm{LB}$ and diluted to give approximately $5 \times 10^{5} \mathrm{CFU} / \mathrm{ml}$. In each assay peptide solutions were added to each bacteria dilution, incubated for 4 hours and samples were plated on Petri dishes and incubated at $37^{\circ} \mathrm{C}$ overnight.

\section{Liposome preparation}

Large unilamellar vesicles (LUV) of a defined size (about $200 \mathrm{~nm}$ ) were prepared from a vacuum-drying lipids chloroform solution by extrusion through 800, 400 and $200 \mathrm{~nm}$ polycarbonate membranes as previously described [16]. The lipid suspension was frozen and thawed several times prior extrusion. Liposomes containing DOPC/DOPG (3:2 molar ratio) were obtained. A $1 \mathrm{mM}$ stock solution of liposome suspension in 10 $\mathrm{mM}$ Tris- $\mathrm{HCl}, 0.1 \mathrm{M} \mathrm{NaCl}, \mathrm{pH} 7.4$ was prepared.

\section{Fluorescence measurements}

Tryptophan (Trp) fluorescence emission spectra were recorded using a $280 \mathrm{~nm}$ excitation wavelength. Slits were set at $2 \mathrm{~nm}$ for excitation and 5-10 nm for emission. Emission spectra were recorded from 300 to $400 \mathrm{~nm}$ at a scan rate of $60 \mathrm{~nm} / \mathrm{min}$, in a 10 x $10 \mathrm{~mm}$ cuvette with stirring immediately after sample mixing. Protein and peptide spectra at $0.5 \mu \mathrm{M}$ in $10 \mathrm{mM}$ Hepes, $\mathrm{pH} 7.4$ buffer were obtained at $25^{\circ} \mathrm{C}$ in the absence and presence of $200 \mu \mathrm{M}$ liposome suspension, $200 \mu \mathrm{M}$ LPS (assuming a $90000 \mathrm{~g} / \mathrm{mol}$ molecular weight) or $200 \mu \mathrm{M}$ LTA (calculated from a $2200 \mathrm{MW}$ reference value). Fluorescence measurements were performed on a Cary Eclipse Spectrofluorimeter. Spectra in the presence of liposomes were corrected for light scattering, by subtracting the corresponding LUV background. For each condition 3 spectra were averaged. The fluorescence spectra were also calculated as a function of the frequency scale (wave number) and adjusted using a log-normal function as detailed previously [16].

Depth-dependent fluorescence quenching experiments using labelled brominated lipids Quenching of protein Trp residues by brominated lipids was introduced to analyze the relative location of both $\operatorname{Trp} 10$ and $\operatorname{Trp} 35$ residues upon membrane interaction. LUV of DOPC/DOPG (3:2 molar ratio) were prepared as previously described [16], containing either $(6,7)-,(9,10)$-, or $(11,12)-\mathrm{Br}_{2}-\mathrm{PC}$. Brominated lipids were mixed at increasing percentage from $20 \%$ up to $80 \%$ with unlabelled DOPC/DOPG vesicles. The emission fluorescence spectra were recorded at $25^{\circ} \mathrm{C}$ using the following conditions: $10 \mathrm{mM}$ Tris$\mathrm{HCl}, \mathrm{pH} 7.4$, buffer, $0.5 \mu \mathrm{M}$ protein concentration and $200 \mu \mathrm{M}$ liposome concentration, excitation wavelength of $280 \mathrm{~nm}$, excitation and emission slits set to 2 and $10 \mathrm{~nm}$ respectively. For each condition 3 spectra were averaged. The quenching efficiency of brominated lipids on protein Trp fluorescence was determined by calculating the area under the fluorescence spectra in range of 320 to $380 \mathrm{~nm}$. Relative fluorescence intensities $\left(F_{0} / F\right)$ were compared, where $F_{0}$ is the fluorescence intensity in the absence 
of quencher. To calculate the depth of insertion of the protein in the lipid bilayer the distribution analysis (DA) was employed, as previously detailed [16].

\section{ANTS/DPX liposome leakage assay}

The ANTS/DPX liposome leakage fluorescence assay was performed as described previously $[16,28]$. Briefly, a unique population of large unilamelar vesicles (LUV) of DOPC/DOPG (3:2 molar ratio) lipids was obtained containing $12.5 \mathrm{mM}$ ANTS, $45 \mathrm{mM}$ DPX, $20 \mathrm{mM} \mathrm{NaCl}, 10 \mathrm{mM}$ Tris-HCl, pH 7.5. The ANTS/DPX liposome suspension was diluted to $30 \mu \mathrm{M}$ final concentration and was incubated at room temperature in the presence of the ECP or the synthetic peptides. The leakage activity was assayed at different polypeptide concentrations, up to $8 \mu \mathrm{M}$, by following the release of the liposome content. Fluorescence was measured using a $386 \mathrm{~nm}$ excitation wavelength and $535 \mathrm{~nm}$ emission wavelength. Slits were set at $5 \mathrm{~nm}$ and $10 \mathrm{~nm}$ for excitation and emission respectively. The percentage of leakage $(\% L)$ produced by the proteins after 1 $\mathrm{h}$ of incubation with the liposomes was calculated with the following equation: $(\% L)=$ $100\left(F \mathrm{p}-F_{0}\right) /\left(F_{100}-F_{0}\right)$; where $F \mathrm{p}$ is the final fluorescence intensity after addition of the protein $(1 \mathrm{~h}), F_{0}$ and $F_{100}$ are the fluorescence intensities before addition of the protein and after addition of $0.5 \%$ Triton X100. For each protein concentration three calculated leakage values were averaged. Leakage could not be quantified for those samples where the assay conditions trigger the LUV precipitation, as LUV samples incubated with high ECP protein concentrations.

\section{LUV liposome aggregation}

Aggregation of LUV lipid vesicles was monitored by measuring the scattering intensity with the excitation and emission wavelengths set at $470 \mathrm{~nm}$ using a Cary Eclypse spectrofluorimeter and cuvettes with an optical path of $1 \mathrm{~cm}$. Prior to the addition of ECP and peptides, the vesicles were allowed to equilibrate for $15 \mathrm{~min}$ at room temperature. The buffer used was $10 \mathrm{mM}$ HEPES, $\mathrm{pH}$ 7.4. Final assay conditions were: $200 \mu \mathrm{M}$ lipid concentration and from 0.04 to $4 \mu \mathrm{M}$ polypeptide range concentration, in $10 \mathrm{mM}$ HEPES, pH 7.4 buffer. After $30 \mathrm{~min}$ of incubation at room temperature, the signal was read at $90^{\circ}$ from the excitation beam with slits at 5 and $10 \mathrm{~nm}$.

\section{Circular dichroism spectroscopy}

The far-UV circular dichroism (CD) spectra were collected with a JASCO J-715 spectropolarimeter. Spectra were recorded from 250 up to $190 \mathrm{~nm}$, at $1 \mathrm{~nm}$ intervals, 1 $\mathrm{nm}$ bandwidth, with a scan speed of $10 \mathrm{~nm} / \mathrm{min}$, at $25^{\circ} \mathrm{C} .0 .2 \mathrm{~cm}$ pathlength cuvettes were used. Mean-residue ellipticity $[\theta]\left(\operatorname{deg~} \mathrm{cm}^{2} \mathrm{dmol}^{-1}\right)$ was calculated using the formula:

$[\theta]=\frac{\theta(M R W)}{10 c l}$

where $M R W$ is the mean residue molecular weight of the protein, $c$ is the protein concentration and $l$ is the cell path length. Data of 4 consecutive scans was averaged and a linear smoothing from each 5 consecutive measurements was applied. ECP and peptides spectra in the absence and presence of SDS and LPS were recorded. 4-8 $\mu \mathrm{M}$ ECP or peptide concentrations diluted in phosphate buffer $5 \mathrm{mM}, \mathrm{pH} 7,5$, and $1 \mathrm{mM}$ SDS and $1 \mathrm{mM}$ LPS (assuming a $90000 \mathrm{~g} / \mathrm{mol} \mathrm{molecular} \mathrm{weight)} \mathrm{concentration} \mathrm{were}$ used. Samples were centrifuged for $5 \mathrm{~min}$ at $10.000 \mathrm{~g}$ before use. For near -UV CD, spectra were recorded from 340 up to $255 \mathrm{~nm}$, at $1 \mathrm{~nm}$ intervals, $1 \mathrm{~nm}$ bandwidth, with 
a scan speed of $10 \mathrm{~nm} / \mathrm{min}$, at $25^{\circ} \mathrm{C}$ and $1 \mathrm{~cm}$ pathlength cuvettes were used. Data of 4 consecutive scans was averaged. ECP and peptides spectra in the absence and presence of LPS were recorded. $80-100 \mu \mathrm{M}$ ECP or peptide concentrations diluted in phosphate buffer $5 \mathrm{mM}$, pH 7,5, and $1 \mathrm{mM}$ LPS (assuming a $90000 \mathrm{~g} / \mathrm{mol}$ molecular weight) concentration were used. Percentage of each secondary structure was estimated using the JASCO software, based on the calculation method described by Yang and coworkers [47].

\section{Bioinformatic analysis tools for peptide characterization}

Physicochemical properties of peptides ( $\mathrm{pI}$ and net charge) were predicted using the Swiss-Prot expasy server (http://www.expasy.ch/sprot/). Transmembrane- prediction domain analysis was performed using the Membrane Protein Explorer server (MPEx; http://blanco.biomol.uci.edu/mpex). Sequences with aggregation propensity were predicted using the Aggrescan server [41].

\section{Bacterial cytoplasmic membrane depolarization assay}

Membrane depolarization was monitored as previously described [17], using the DiSC3(5) lipophilic dye that changes its fluorescence intensity in response to changes in transmembrane potential. E. coli and S. aureus cells were grown to mid-exponential phase and resuspended in $5 \mathrm{mM}$ Hepes- $\mathrm{KOH}, 20 \mathrm{mM}$ glucose, and $100 \mathrm{mM} \mathrm{KCl}$ at $\mathrm{pH}$ 7.2 to an $\mathrm{OD}_{600}$ of 0.05. DiSC3(5) was added. Changes in the fluorescence due to the alteration of the cytoplasmic membrane potential were continuously monitored at $20{ }^{\circ} \mathrm{C}$ by fluorescence emission at $670 \mathrm{~nm}$ using an excitation wavelength of $620 \mathrm{~nm}$. When the dye uptake was maximal, as indicated by a stable reduction in the fluorescence because of quenching of the accumulated dye at the membrane, polypeptide samples were added at a final concentration of $4 \mu \mathrm{M}$. All conditions were assayed in duplicate. The time necessary to reach a stabilized maximum fluorescence reading was recorded for each condition.

\section{Fluorescent probe displacement assay for lipolysaccharide binding}

Lipolysaccharide (LPS) binding was assessed using the fluorescent probe BODIPY TR cadaverine $(\mathrm{BC})$ as previously described [17]. BC binds strongly to native LPS, specifically recognizing the Lipid A portion. LPS binding assays were carried out in 5 $\mathrm{mM}$ Hepes buffer, $\mathrm{pH}$ 7.5. The displacement assay was performed by the addition of 1$2 \mu \mathrm{l}$ aliquots of a stock solution of ECP and peptides to $1 \mathrm{ml}$ of a continuously stirred mixture of LPS at $10 \mu \mathrm{g} / \mathrm{ml}$ and BC $(10 \mu \mathrm{M})$. The BC excitation wavelength was 580 $\mathrm{nm}$ and emission wavelength was $620 \mathrm{~nm}$. Excitation and emission slits were set at 2.5 $\mathrm{nm}$ and $20 \mathrm{~nm}$, respectively. Final values correspond to an average of 4 replicates. Quantitative effective displacement values $\left(\mathrm{ED}_{50}\right)$ were calculated. The $\mathrm{ED}_{50}$ was computed at the midpoint of the fluorescent signal versus the protein concentration of the displacement curve by a curve-fitting of the data to the equation

$$
O F=\frac{F_{0}-F}{F_{0}-F_{\text {max }}}
$$

where $O F$ is the occupancy factor, $F_{0}$ the fluorescence intensity of $\mathrm{BC}$ alone, $F_{\max }$ is the intensity in the presence of LPS at a saturation concentration and $F$ the intensities of the LPS:BC mixtures at each displacer concentrations. Polymyxin B (PMB) and RNase A were used as positive and negative controls, respectively. 


\section{Scanning electron microscopy (SEM)}

One-ml cultures of E. coli and S. aureus were grown at $37^{\circ} \mathrm{C}$ to mid-exponential phase $\left(\mathrm{OD}_{600}\right.$ of 0.4$)$ and incubated with $10 \mu \mathrm{M}$ of ECP and the derived peptides in phosphate-buffered saline (PBS) at room temperature. Sample aliquots were taken up to $4 \mathrm{~h}$ of incubation and prepared for SEM analysis as previously described [17]. The micrographs were viewed at $15 \mathrm{kV}$ accelerating voltage in a Hitachi S-570 scanning electron microscope, and a secondary electron image of cells for topography contrast was collected at several magnifications.

\section{Transmission Electron Microscopy (TEM).}

Mid-logarithmic phase E. coli and S. aureus cells $\left(\mathrm{OD}_{600} \sim 0.4\right)$ were incubated with 10 $\mu \mathrm{M}$ ECP and peptides for $4 \mathrm{~h}$. After treatment, bacterial pellets were prefixed with $2.5 \%$ glutaraldehyde and $2 \%$ paraformaldehyde in $0.1 \mathrm{M}$ cacodylate buffer at $\mathrm{pH} 7.4$ for $2 \mathrm{~h}$ at $4{ }^{\circ} \mathrm{C}$ and post-fixed in $1 \%$ osmium tetroxide buffered in $0.1 \mathrm{M}$ cacodylate at $\mathrm{pH} 7.4$ for $2 \mathrm{~h}$ at $4{ }^{\circ} \mathrm{C}$. The samples were dehydrated in acetone $(50,70,90,95$, and $100 \%)$. The cells were immersed in EPON resin, and ultrathin sections were examined in a JEOL JEM 2011 microscope (Jeol Ltd., Tokio, Japan).

\section{ACKNOWLEDGMENTS}

Scanning electron microscopy was performed at the Servei de Microscopia of the Universitat Autònoma de Barcelona (UAB). We thank Francisca Cardoso and Francesc Bohils for their assistance in electron micrography preparation. Fluorescence assays were done at the Laboratori d'Anàlisi i Fotodocumentació, Fac. Biociències, UAB. CD spectra were recorded at the Servei d'Anàlisi Química, Fac. Ciències, UAB. This project was funded by a grant from Ministerio de Educación y Cultura (Grants BMC2003-08485-C02-01 and BFU2006-15543-C02-01) and by the Fundació La Marato de TV3 (TV3-031110). M.T. was the recipient of a predoctoral fellowship from the Generalitat de Catalunya. Work at Universitat Pompeu Fabra was supported by the Spanish Ministries of Health (Fondo de Investigaciones Sanitarias grant PI040885), Education and Science (BIO2005-07592-CO2-02 and PET2006-00139-00), and by Generalitat de Catalunya (SGR00494). 


\section{REFERENCES}

1 Powers, J. P. and Hancock, R. E. (2003) The relationship between peptide structure and antibacterial activity. Peptides 24, 1681-1691

2 Lohner, K. and Blondelle, S. E. (2005) Molecular mechanisms of membrane perturbation by antimicrobial peptides and the use of biophysical studies in the design of novel peptide antibiotics. Comb Chem High Throughput Screen 8, 241-256

3 Rivas, L., Luque-Ortega, J. R. and Andreu, D. (2008) Amphibian antimicrobial peptides and Protozoa: Lessons from parasites. Biochim Biophys Acta

4 Hancock, R. E. and Sahl, H. G. (2006) Antimicrobial and host-defense peptides as new anti-infective therapeutic strategies. Nat Biotechnol 24, 1551-1557

5 Gudmundsson, G. H. and Agerberth, B. (1999) Neutrophil antibacterial peptides, multifunctional effector molecules in the mammalian immune system. J Immunol Methods 232, 45-54

6 During, K., Porsch, P., Mahn, A., Brinkmann, O. and Gieffers, W. (1999) The non-enzymatic microbicidal activity of lysozymes. FEBS Lett 449, 93-100

7 Nibbering, P. H., Ravensbergen, E., Welling, M. M., van Berkel, L. A., van Berkel, P. H., Pauwels, E. K. and Nuijens, J. H. (2001) Human lactoferrin and peptides derived from its $\mathrm{N}$ terminus are highly effective against infections with antibiotic-resistant bacteria. Infect Immun 69, 1469-1476

8 Canny, G. and Levy, O. (2008) Bactericidal/permeability-increasing protein (BPI) and BPI homologs at mucosal sites. Trends Immunol 29, 541-547

9 Zanetti, M., Gennaro, R. and Romeo, D. (1995) Cathelicidins: a novel protein family with a common proregion and a variable $\mathrm{C}$-terminal antimicrobial domain. FEBS Lett 374, 1-5

10 Ayabe, T., Satchell, D. P., Pesendorfer, P., Tanabe, H., Wilson, C. L., Hagen, S. J. and Ouellette, A. J. (2002) Activation of Paneth cell alpha-defensins in mouse small intestine. J Biol Chem 277, 5219-5228

11 Hogan, S. P., Rosenberg, H. F., Moqbel, R., Phipps, S., Foster, P. S., Lacy, P., Kay, A. B. and Rothenberg, M. E. (2008) Eosinophils: biological properties and role in health and disease. Clin Exp Allergy 38, 709-750

12 Zagai, U., Skold, C. M., Trulson, A., Venge, P. and Lundahl, J. (2004) The effect of eosinophils on collagen gel contraction and implications for tissue remodelling. Clin Exp Immunol 135, 427-433

13 Gomes, I., Mathur, S. K., Espenshade, B. M., Mori, Y., Varga, J. and Ackerman, S. J. (2005) Eosinophil-fibroblast interactions induce fibroblast IL-6 secretion and extracellular matrix gene expression: implications in fibrogenesis. J Allergy Clin Immunol 116, 796-804

14 Boix, E., Torrent, M., Sánchez, D. and Nogués, M. V. (2008) The Antipathogen Activities of Eosinophil Cationic Protein. Current Pharm Biotec. 9, 141-152

15 Lehrer, R. I., Szklarek, D., Barton, A., Ganz, T., Hamann, K. J. and Gleich, G. J. (1989) Antibacterial properties of eosinophil major basic protein and eosinophil cationic protein. J Immunol 142, 4428-4434

16 Torrent, M., Cuyas, E., Carreras, E., Navarro, S., Lopez, O., de la Maza, A., Nogues, M. V., Reshetnyak, Y. K. and Boix, E. (2007) Topography studies on the membrane interaction mechanism of the eosinophil cationic protein. Biochemistry 46, 720-733 
17 Torrent, M., Navarro, S., Moussaoui, M., Nogues, M. V. and Boix, E. (2008) Eosinophil cationic protein high-affinity binding to bacteria-wall lipopolysaccharides and peptidoglycans. Biochemistry 47, 3544-3555

18 Torrent, M., Sánchez, D., Buzón, V., Nogués, M. V., Cladera, J. and Boix, E. (in press) Comparison of the membrane interaction mechanism of two antimicrobial RNases: RNase 3/ECP and RNase 7. BBA Biomembranes

19 Boix, E. and Nogues, M. V. (2007) Mammalian antimicrobial proteins and peptides: overview on the RNase A superfamily members involved in innate host defence. Mol Biosyst 3, 317-335

20 Pizzo, E., Varcamonti, M., Di Maro, A., Zanfardino, A., Giancola, C. and D'Alessio, G. (2008) Ribonucleases with angiogenic and bactericidal activities from the Atlantic salmon. Febs J 275, 1283-1295

21 Hooper, L. V., Stappenbeck, T. S., Hong, C. V. and Gordon, J. I. (2003) Angiogenins: a new class of microbicidal proteins involved in innate immunity. Nat Immunol 4, 269-273

22 Cho, S. and Zhang, J. (2007) Zebrafish ribonucleases are bactericidal: implications for the origin of the vertebrate RNase A superfamily. Mol Biol Evol 24, 1259-1268

23 Rosenberg, H. F. (2008) RNase A ribonucleases and host defense: an evolving story. J Leukoc Biol 83, 1079-1087

24 Pizzo, E. and D'Alessio, G. (2007) The success of the RNase scaffold in the advance of biosciences and in evolution. Gene 406, 8-12

25 Rosenberg, H. F. (2008) Eosinophil-derived neurotoxin/ RNase 2: connecting the Past, the Present and the Future. Current Pharm Biotec. 9, 135-140

26 Hilpert, K., Volkmer-Engert, R., Walter, T. and Hancock, R. E. (2005) Highthroughput generation of small antibacterial peptides with improved activity. Nat Biotechnol 23, 1008-1012

27 Carreras, E., Boix, E., Navarro, S., Rosenberg, H. F., Cuchillo, C. M. and Nogues, M. V. (2005) Surface-exposed amino acids of eosinophil cationic protein play a critical role in the inhibition of mammalian cell proliferation. Mol Cell Biochem 272, 1-7

28 Carreras, E., Boix, E., Rosenberg, H. F., Cuchillo, C. M. and Nogues, M. V. (2003) Both aromatic and cationic residues contribute to the membrane-lytic and bactericidal activity of eosinophil cationic protein. Biochemistry 42, 6636-6644

29 Marshall, G. R., Feng, J. A. and Kuster, D. J. (2008) Back to the future: ribonuclease A. Biopolymers 90, 259-277

30 Reshetnyak, Y. K., Koshevnik, Y. and Burstein, E. A. (2001) Decomposition of protein tryptophan fluorescence spectra into log-normal components. III. Correlation between fluorescence and microenvironment parameters of individual tryptophan residues. Biophys J 81, 1735-1758

31 Nikolovski, Z., Buzon, V., Ribo, M., Moussaoui, M., Vilanova, M., Cuchillo, C. M., Cladera, J. and Nogues, M. V. (2006) Thermal unfolding of eosinophil cationic protein/ribonuclease 3: a nonreversible process. Protein Sci 15, 28162827

32 Boix, E., Leonidas, D. D., Nikolovski, Z., Nogues, M. V., Cuchillo, C. M. and Acharya, K. R. (1999) Crystal structure of eosinophil cationic protein at $2.4 \mathrm{~A}$ resolution. Biochemistry 38, 16794-16801

33 Venge, P., Bystrom, J., Carlson, M., Hakansson, L., Karawacjzyk, M., Peterson, C., Seveus, L. and Trulson, A. (1999) Eosinophil cationic protein (ECP): 
molecular and biological properties and the use of ECP as a marker of eosinophil activation in disease. Clin Exp Allergy 29, 1172-1186

34 Zhang, J., Rosenberg, H. F. and Nei, M. (1998) Positive Darwinian selection after gene duplication in primate ribonuclease genes. Proc Natl Acad Sci U S A 95, 3708-3713

35 Brown, K. L. and Hancock, R. E. (2006) Cationic host defense (antimicrobial) peptides. Curr Opin Immunol 18, 24-30

36 Andreu, D. and Rivas, L. (1998) Animal antimicrobial peptides: an overview. Biopolymers 47, 415-433

37 Bulet, P., Stocklin, R. and Menin, L. (2004) Anti-microbial peptides: from invertebrates to vertebrates. Immunol Rev 198, 169-184

38 Nitto, T., Dyer, K. D., Czapiga, M. and Rosenberg, H. F. (2006) Evolution and function of leukocyte RNase A ribonucleases of the avian species, Gallus gallus. J Biol Chem 281, 25622-25634

39 Huang, Y. C., Lin, Y. M., Chang, T. W., Wu, S. J., Lee, Y. S., Chang, M. D., Chen, C., Wu, S. H. and Liao, Y. D. (2007) The flexible and clustered lysine residues of human ribonuclease 7 are critical for membrane permeability and antimicrobial activity. J Biol Chem 282, 4626-4633

40 Schroder, J. M. and Harder, J. (2006) Antimicrobial skin peptides and proteins. Cell Mol Life Sci 63, 469-486

41 Conchillo-Sole, O., de Groot, N. S., Aviles, F. X., Vendrell, J., Daura, X. and Ventura, S. (2007) AGGRESCAN: a server for the prediction and evaluation of "hot spots" of aggregation in polypeptides. BMC Bioinformatics 8, 65

42 Fan, T. C., Fang, S. L., Hwang, C. S., Hsu, C. Y., Lu, X. A., Hung, S. C., Lin, S. C. and Chang, D. T. (2008) Characterization of molecular interactions between eosinophil cationic protein and heparin. J Biol Chem 283, 25468-25474

43 Ulrich, M., Petre, A., Youhnovski, N., Promm, F., Schirle, M., Schumm, M., Pero, R. S., Doyle, A., Checkel, J., Kita, H., Thiyagarajan, N., Acharya, K. R., Schmid-Grendelmeier, P., Simon, H. U., Schwarz, H., Tsutsui, M., Shimokawa, H., Bellon, G., Lee, J. J., Przybylski, M. and Doring, G. (2008) Posttranslational tyrosine nitration of eosinophil granule toxins mediated by eosinophil peroxidase. J Biol Chem

44 Gorr, S. U., Sotsky, J. B., Shelar, A. P. and Demuth, D. R. (2008) Design of bacteria-agglutinating peptides derived from parotid secretory protein, a member of the bactericidal/permeability increasing-like protein family. Peptides $\mathbf{2 9}$, 2118-2127

45 Fields, G. B. and Noble, R. L. (1990) Solid phase peptide synthesis utilizing 9fluorenylmethoxycarbonyl amino acids. Int J Pept Protein Res 35, 161-214

46 Boix, E., Nikolovski, Z., Moiseyev, G. P., Rosenberg, H. F., Cuchillo, C. M. and Nogues, M. V. (1999) Kinetic and product distribution analysis of human eosinophil cationic protein indicates a subsite arrangement that favors exonuclease-type activity. J Biol Chem 274, 15605-15614

47 Yang, J. T., Wu, C. S. and Martinez, H. M. (1986) Calculation of protein conformation from circular dichroism. Methods Enzymol 130, 208-269 


\section{FIGURE LEGENDS}

Figure 1. Graphical representation of the 3D structure of ECP drawn with Pymol (DeLano Scientific LLC) and ECP primary sequence and its secondary elements drawn with ESPript. The main chains of regions 1-19, 24-45 and 1-45 are labeled in grey tones and the corresponding primary sequence is boxed.

Figure 2. Depolarization activity on E. coli (A) and S. aureus (B) cells determined by the $\mathrm{DiSC}_{3}(5)$ dye assay. Bacterial cells were grown at $37^{\circ} \mathrm{C}$ to mid-exponential phase $\left(\mathrm{OD}_{600}=0.4\right)$, and resuspended in $5 \mathrm{mM}$ Hepes-KOH, $20 \mathrm{mM}$ glucose, $100 \mathrm{mM} \mathrm{KCl}$, $\mathrm{pH} 7.2$, to an $\mathrm{OD}_{600}$ of 0.05 . $\operatorname{DiSC}_{3}(5)$ was added and when the dye uptake was maximal, polypeptides in $5 \mathrm{mM}$ Hepes-KOH buffer $\mathrm{pH} 7.2$ were added at a final concentration of $4 \mu \mathrm{M}$. The increase in fluorescence intensity (FI) registers the dye release upon reduction of the transmembrane potential. ECP (circles), ECP(1-45) (triangles), ECP(24-45) (squares) and ECP(1-19) (rhombus). No activity is registered for $S$. aureus cells incubated with ECP(1-19).

Figure 3. Transmission electron microscopy of $E$. coli (left panel) and scanning electron microscopy of E. coli (right panel) incubated with $10 \mu \mathrm{M}$ of ECP and the peptides for 3 h. From up to bottom: control cells, ECP(1-19), ECP(24-45), ECP(1-45) and ECP. Magnification scale is indicated at the bottom of each micrograph.

Figure 4. Depth-dependent fluorescence quenching profiles calculated by distribution analysis to visualize changes in the Trp chromophore $(F)$ fluorescence, normalized to its value in the absence of quenching $\left(F_{0}\right)$, when the quencher is present at certain depths in the bilayer. $h_{m}$ is the average location depth of the Trp residues, calculated from the bilayer center. Liposomes containing DOPC/DOPG $(3: 2)$ were mixed with increasing molar ratios of $(6,7)-\mathrm{Br}_{2}-\mathrm{PC},(9,10)-\mathrm{Br}_{2}-\mathrm{PC}$, or $(11,12)-\mathrm{Br}_{2}-\mathrm{PC}$. Assay conditions were $0.5 \mu \mathrm{M}$ final protein concentration and $200 \mu \mathrm{M}$ liposome concentration. ECP(1-19) (closed squares); ECP(24-45) (closed triangles) and ECP(145) (closed circles).

Figure 5. Peptide action on lipid bilayers. A) Leakage activity was monitored by release of ANTS/DPX liposome content. Percentage of leakage $(\% L)$ produced by the polypeptides after $1 \mathrm{~h}$ incubation with liposomes at room temperature was determined. B) LUV aggregation as a function of polypeptide concentration. LUVs were incubated with of each peptide and aggregation was monitored as an increase of scattering intensity at $470 \mathrm{~nm}$ at $90^{\circ}$ from the excitation beam after $30 \mathrm{~min}$ incubation at room temperature. ECP (empty circles), ECP(1-45) (filled squares), ECP(24-45) (filled triangles) and $\mathrm{ECP}(1-19)$ (filled circles).

Figure 6. Circular dichroism far UV spectra of ECP (A), ECP(1-19) (B), ECP(24-45) (C), ECP(1-45) (D) in the absence (solid line) and presence of SDS (dotted line) and LPS (dashed line). Four consecutive scans were averaged. Mean-residue ellipticity [ $\theta]$ (deg $\mathrm{cm}^{2} \mathrm{dmol}^{-1}$ ) was calculated. Top right insets include the CD near UV spectra in the absence (solid line) and presence (dashed line) of LPS. 
Table I. IC50 and minimal inhibitory concentration (MIC) of ECP and peptides. Bacteria were incubated at $37{ }^{\circ} \mathrm{C}$ overnight in LB and diluted to give approximately $5 \times 10^{5} \mathrm{CFU} / \mathrm{ml}$. Final values were determined from 2 independent experiments performed in triplicate for each peptide concentration.

\begin{tabular}{|c|c|c|c|c|}
\hline \multirow{2}{*}{ Polypeptide } & \multicolumn{2}{|c|}{$\begin{array}{c}\text { Bactericidal activity } \\
\text { (E. coli) }\end{array}$} & \multicolumn{2}{c|}{$\begin{array}{c}\text { Bactericidal activity } \\
\text { (S. aureus) }\end{array}$} \\
\cline { 2 - 5 } & $\mathrm{IC}_{50}(\mu \mathrm{M})$ & $\mathrm{MIC}(\mu \mathrm{M})$ & $\mathrm{IC}_{50}(\mu \mathrm{M})$ & $\mathrm{MIC}(\mu \mathrm{M})$ \\
\hline ECP & $0.045 \pm 0.007$ & $0.30-0.50$ & $0.045 \pm 0.004$ & $0.30-0.50$ \\
\hline R1R45 & $0.058 \pm 0.009$ & $0.5-0.75$ & $0.060 \pm 0.004$ & $0.50-0.75$ \\
\hline T24R45 & $0.282 \pm 0.010$ & $5-10$ & $0.173 \pm 0.002$ & $1.00-2.00$ \\
\hline R1R19 & $2.866 \pm 0.053$ & $50-100$ & $3.579 \pm 2.452$ & $50-100$ \\
\hline
\end{tabular}




\section{B Biochemical Journal Immediate Publication. Published on 18 May 2009 as manuscript BJ20082330}

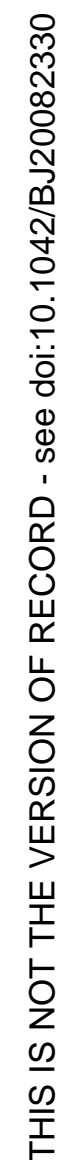

Table II. Maximum position of intrinsec fluorescence spectra of polypeptides in the absence and presence of liposomes, LPS and LTA. Fluorescent emission spectra recorded from 300 to $400 \mathrm{~nm}$ using a $280 \mathrm{~nm}$ excitation wavelength. The data were fitted with a log-normal function as previously detailed [16]. Quantitative effective displacement values $\left(\mathrm{ED}_{50}\right)$ for LPS binding, calculated from Fig. $3 \mathrm{~S}$ curves, are also included. N.D., no displacement is detected.

\begin{tabular}{|c|c|c|c|c|c|c|c||}
\hline \multirow{2}{*}{ Polypeptide } & Control & \multicolumn{2}{|c|}{ DOPC:DOPG 3:2 } & \multicolumn{2}{|c||}{ LPS LTA } \\
\cline { 2 - 9 } & $\lambda_{\max }(\mathrm{nm})$ & $\lambda_{\max }(\mathrm{nm})$ & $\lambda$ shift $(\mathrm{nm})$ & $\lambda_{\max }(\mathrm{nm})$ & $\lambda$ shift $(\mathrm{nm})$ & $\lambda_{\max }(\mathrm{nm})$ & $\lambda$ shift $(\mathrm{nm})$ \\
\hline ECP & 344 & 339 & 5 & 340 & 4 & 340 & 4 \\
\hline R1R45 & 352 & 342 & 10 & 344 & 8 & 342 & 10 \\
\hline T24R45 & 355 & 341 & 14 & 346 & 9 & 344 & 11 \\
\hline R1R19 & 339 & 336 & 3 & 337 & 2 & 337 & 2 \\
\hline
\end{tabular}




\section{FIGURES}
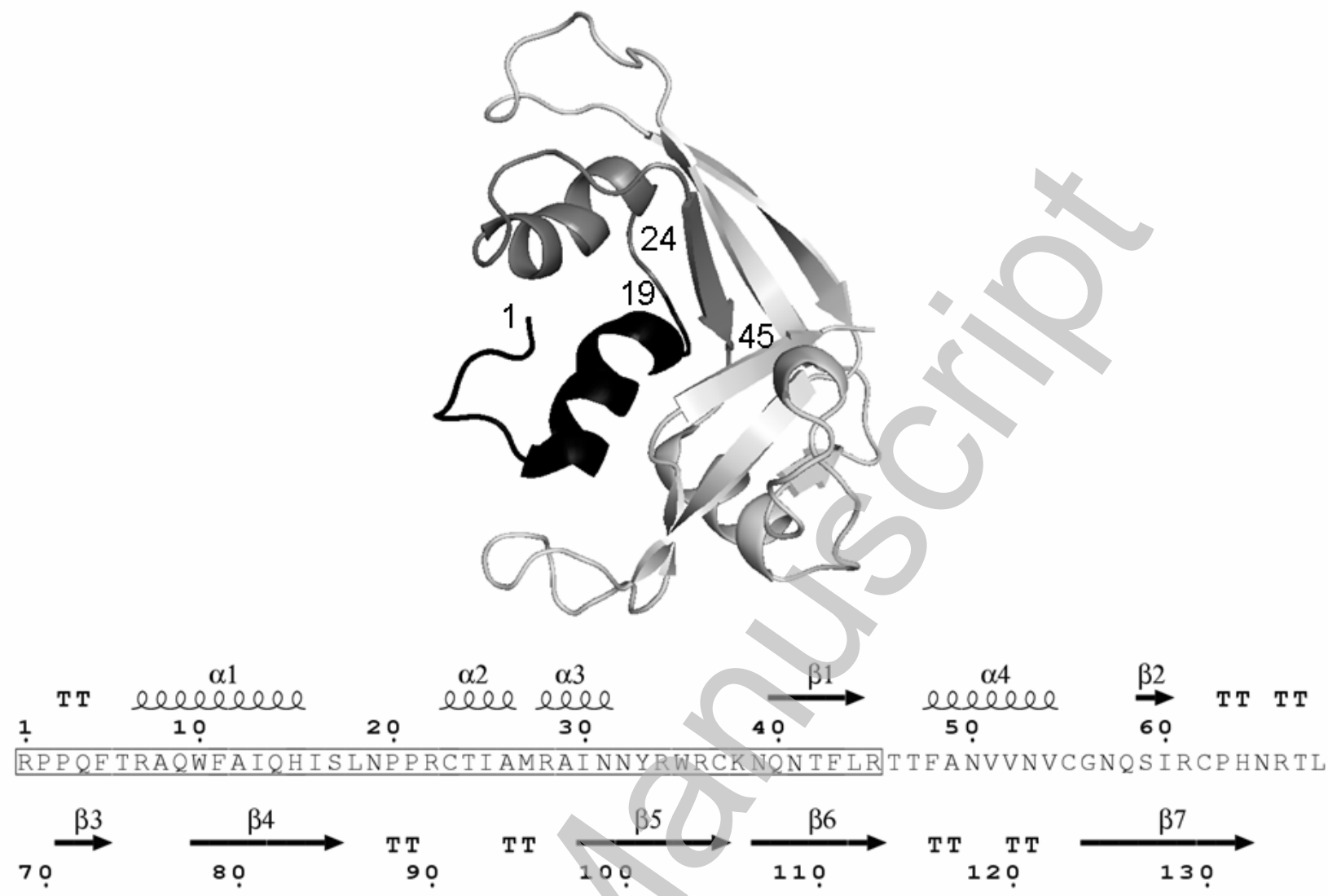

NNCHRSRERVPL LHCDLINPGAQN ISNCRYADRPGRREYVVACDNRDPRDSPRYPVVPVHLDT I

Figure 1 
A

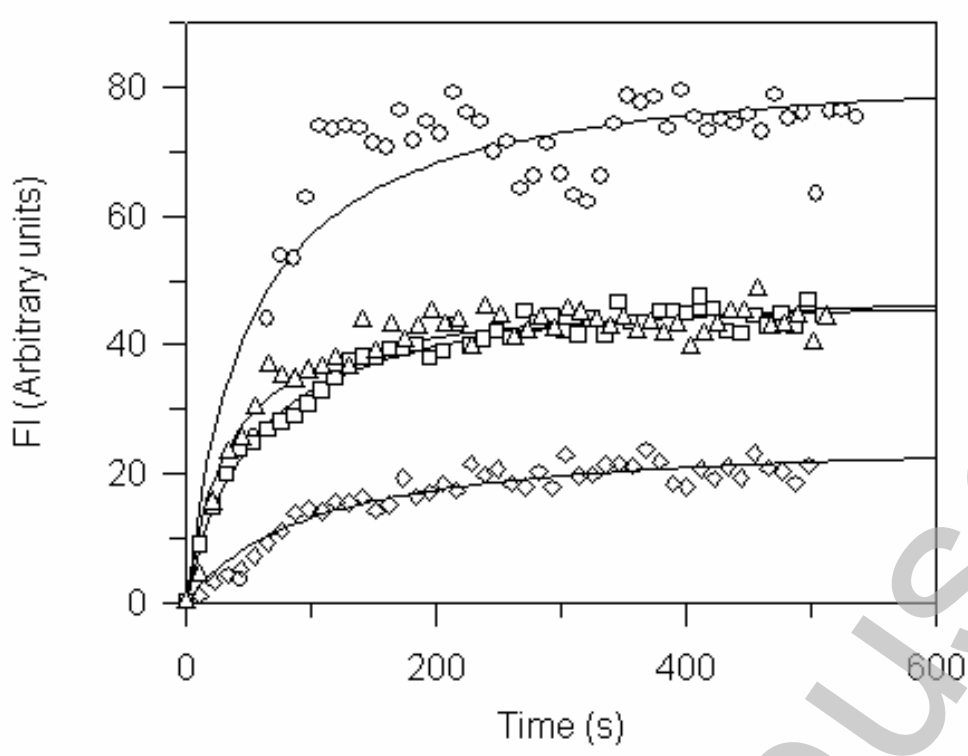

B

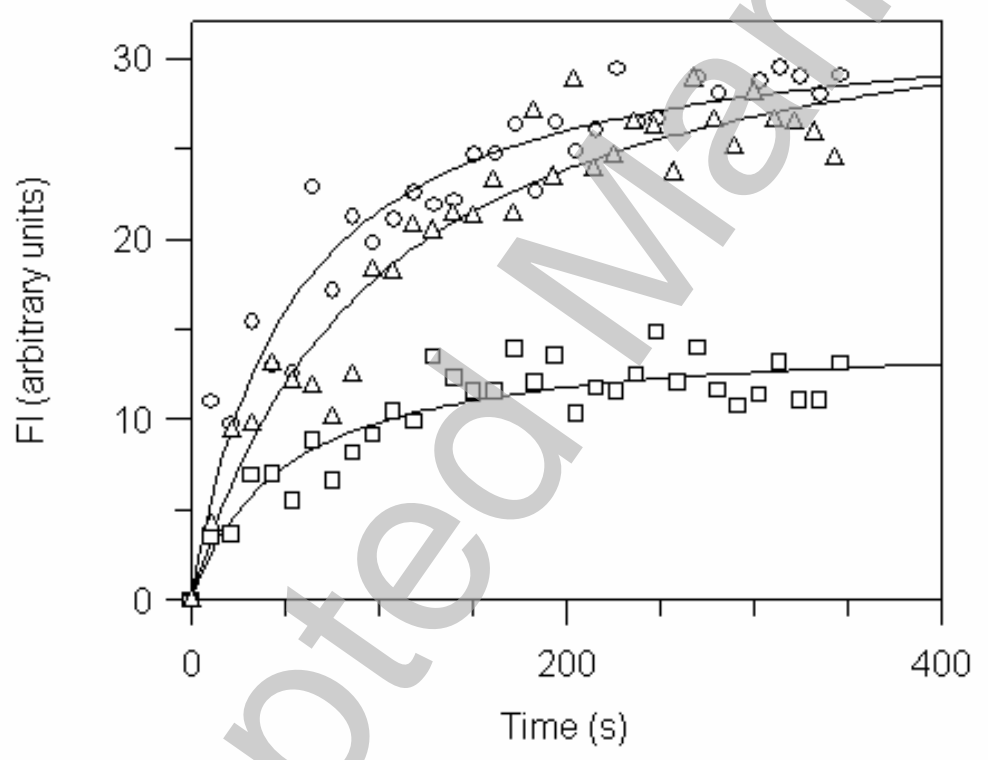

Figure 2 
B Biochemical Journal Immediate Publication. Published on 18 May 2009 as manuscript BJ20082330

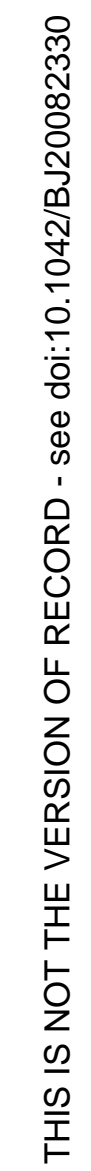
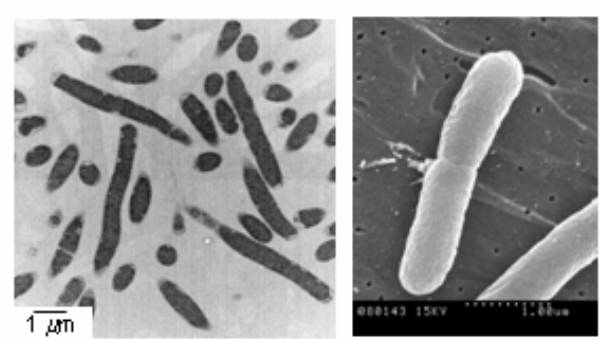

Control
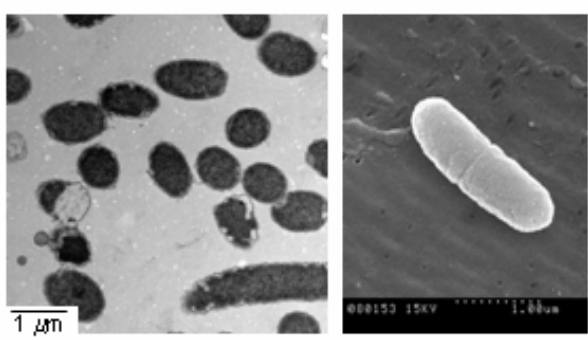

R1N19
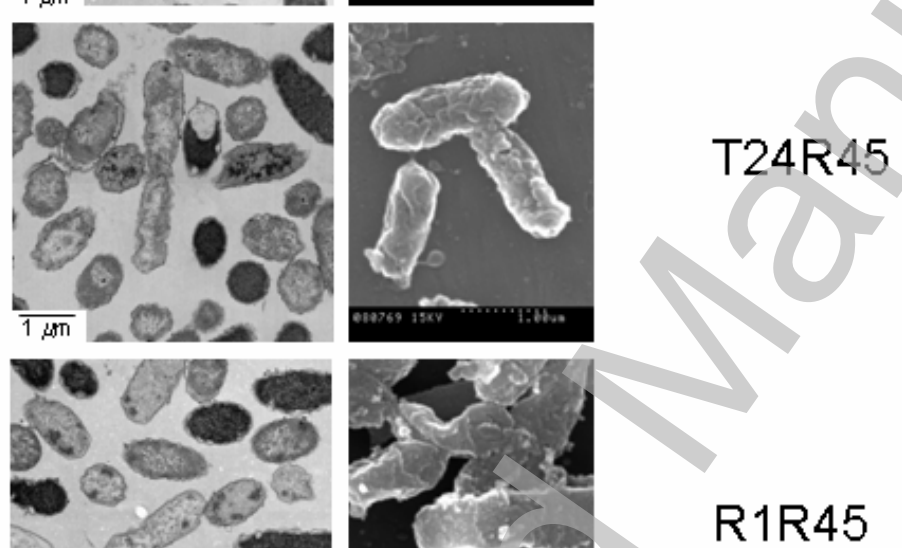

T24R45
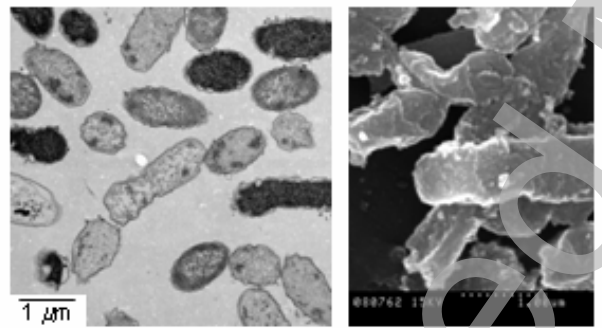

R1R45
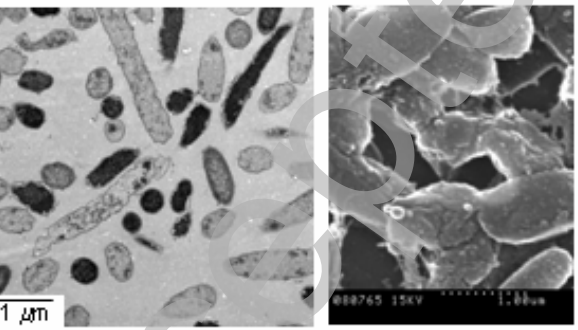

ECP

Figure 3 


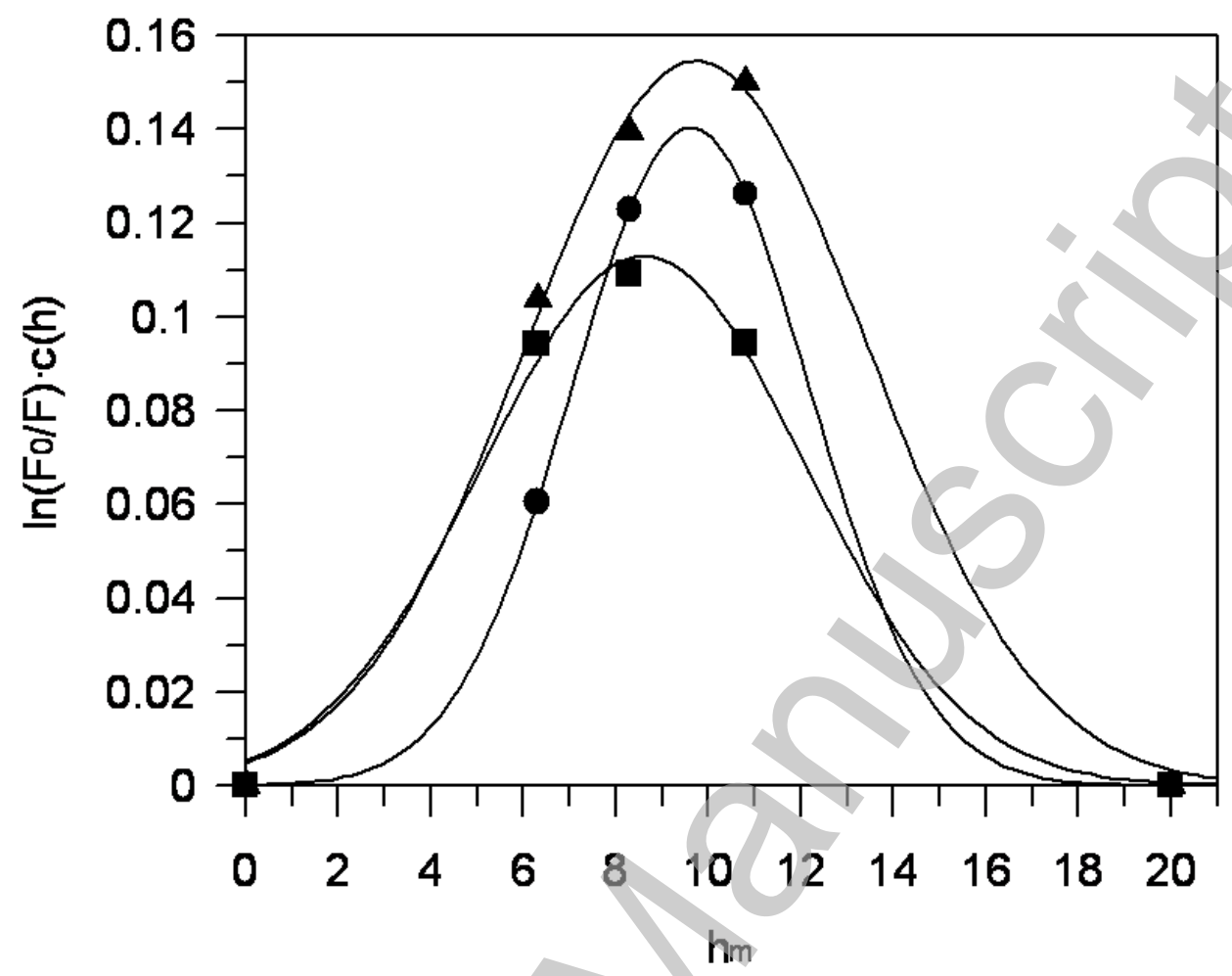

Figure 4. 
A

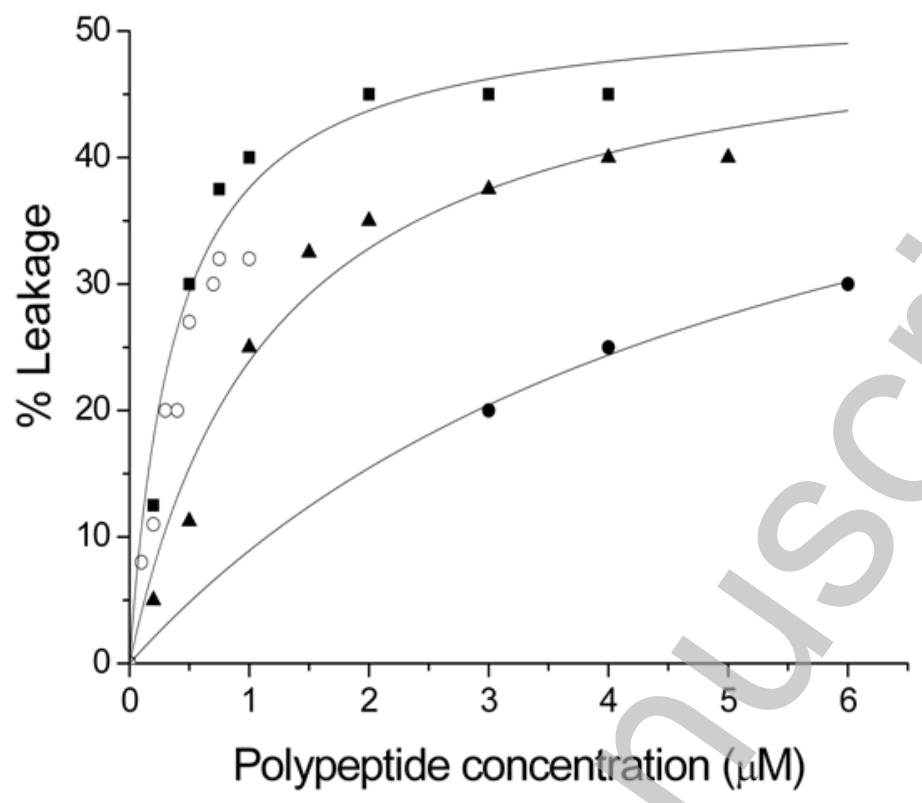

B

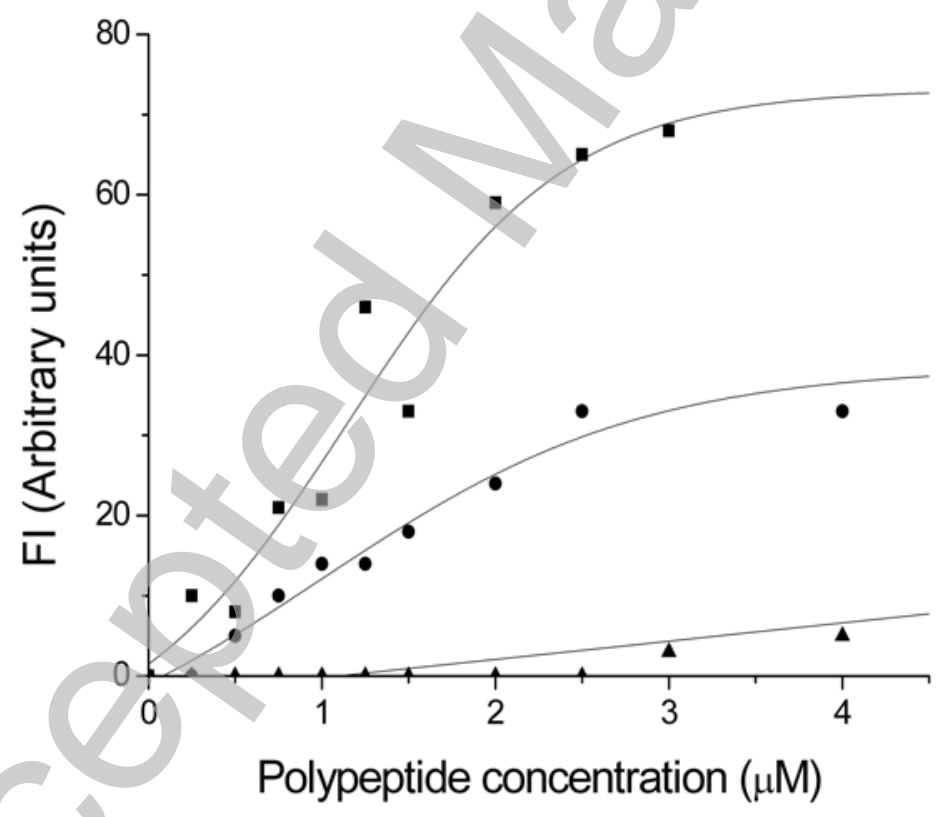

Figure 5 
A

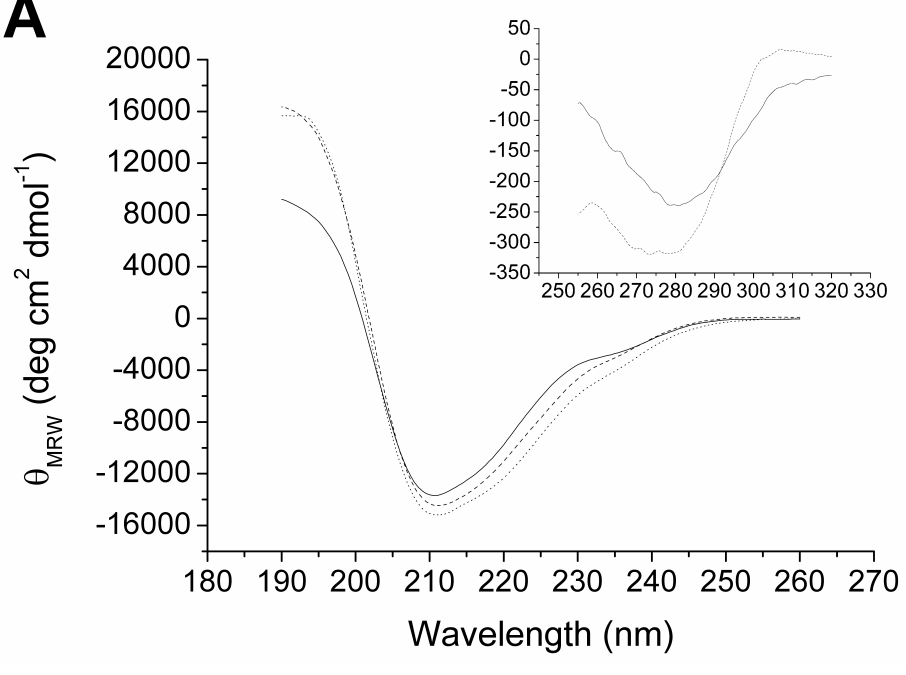

C

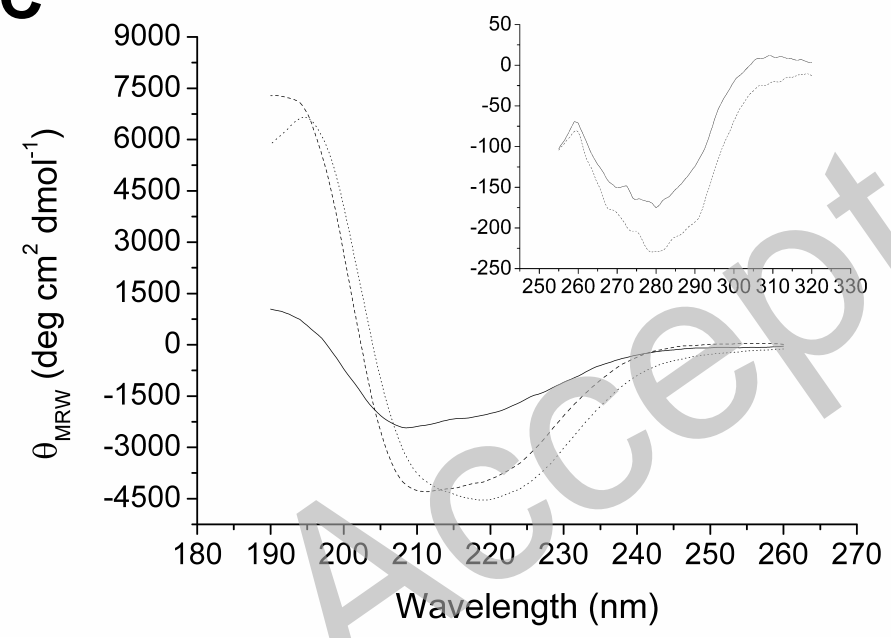

B

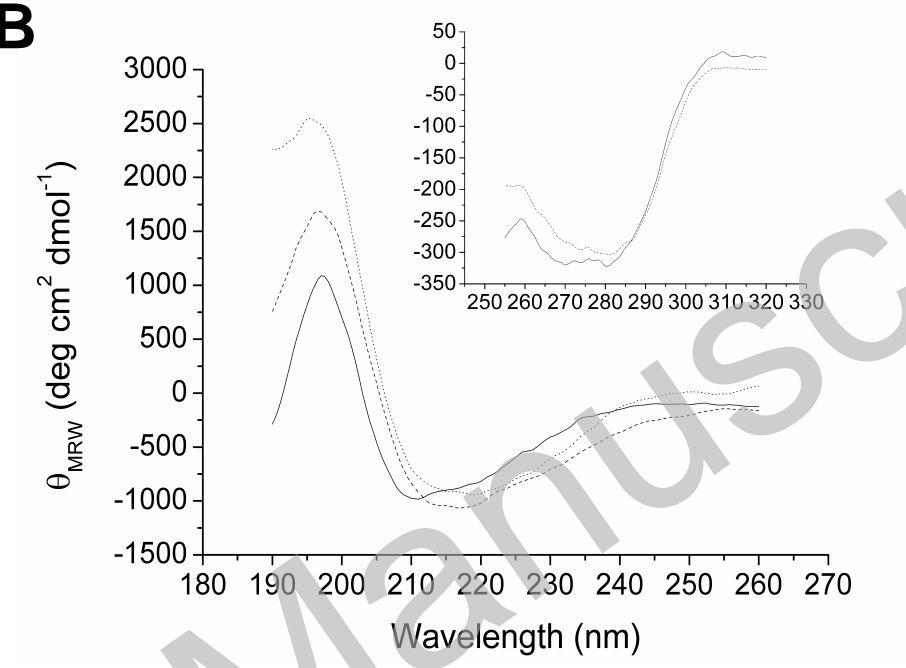

D

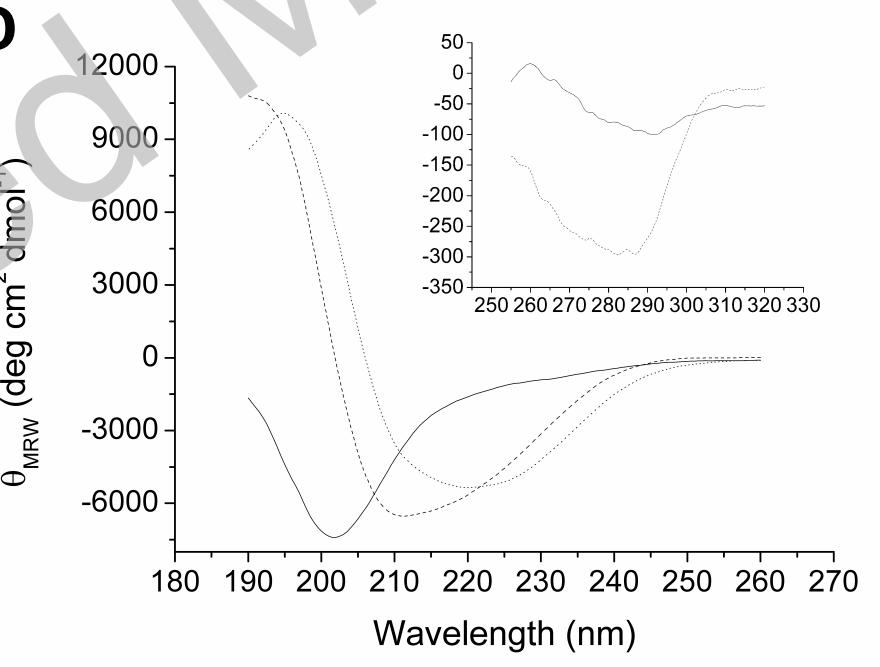

Figure 6 